\title{
Implementation of Integrated Work-Based Learning model to prepare human resource of automotive in Asean Economic Comunity
}

\author{
Suyitno \\ Purworejo Muhammadiyah University \\ Purworejo, Indonnesia \\ yitnoback@yahoo.com
}

\author{
Pardjono, Herminarto Sofyan \\ Universitas Negeri Yogyakarta \\ Yogyakarta, Indonesia \\ pardjono@uny.ac.id
}

\begin{abstract}
The aims of study are to: (1) developing concept of integrated Work-Based Learning (IWBL) in automotive, (2) to study validity which is integrated in Work-Based Learning (IWBL) in automotive, (3) to test process IWBL, (4) to analyze student respond of integrated Work-Based Learning (IWBL) light wheel technic competence. The study was an education research and development. The population is total students who joined practical work in a vocational school (SMK) in Yogyakarta. It is located in some industrial areas and schools in Yogyakarta. The collected data is done by submitting observation sheets, documentation and deep interview. Validation is done by expert judgement. Data analysis is descriptive. The study results showed that: (1) the development of the concept was done in philosophical level, theoretical level, methodological level, and classroom practice, (2) the average of the total score is up to four after validated by 12 experts using guidance book. It means the guidebook of IWBL, Light wheel technic competence in vocational school is valid. (3) The process of IWBL includes (a) structured interaction, (b) student's adaptation, (c) standard work, all indicators works well and achieves the target. (4) The student's respond shows (a) student motivation score which is raised. The average is 4,39. It means IWBL model can motivate the student in learning. (b) Student participation score in IWBL model is increased. The average is 4,22 . It means IWBL can be applied in vocational school, light wheel technic competence.
\end{abstract}

Keywords: Model development, Integrated Work-based learning

\section{INTRODUCTION}

The essentialism said that vocational school must integrate social systems; economy, workship and so on to education itself. (Wardiman, 1988: 41). When it is connected to the economy, it will grow the social life and when it is connected to workship, it will supply the human resource in the industry then when it is connected to social, it will bring social welfare up.

Facing ASEAN Economic Community 2015, (Okezone 30 April 2014), it said the government has a big problem in workship sector in Indonesia. It is because of the human resource. There is any limitation between education and job field. The recommendation is to change the paradigm that the human resource must go in the right place. So in the future, the education is just a supporting item to a prepared human resource in industry field. Murphy, P. \& McCormick, R. (2008, p.48) these education and training responses may be seen as a move to generalize aspects of workplace knowledge, to select out from work that knowledge which is commonly needed. At the same time, the move leaves intact another knowledge that is seen as workplace specific.

In other ways the lower work absorbing the higher redundancy in Indonesia. According to International Monetary Fund (IMF), World Economic Outlook on April 2013 analyzed by BPS (statistic centre) that redundancy in 2012: Indonesia is $5,0 \%$; Malaysia is $3,0 \%$; Singapura is $2,0 \%$, and Thailand is $0,5 \%$. Here, the higher redundancy was because of the huge of the worker. So it made the job field imbalance and focused on one city centre then it will make lack of human resources in the local area. Finally, the competence of the worker is not matched with the requirement. Billet (2011, p.59) “...vocational does not imply $a$ one-way subordination of the person to the practice. Vocation describes work that is fulfilling and meaningful to the individual, such that it helps to provide a sense of self, of personal identity".

It is analyzed that the concept of vocational school through practical work in school or industry is not relevant. The curriculum should fulfil requirement in the industry actually on practical work. It should update job competence in world industry develop the mentality and prepare more required skill to work in the industry. The new concept should make student know how to make good etiquette of work. It is how to interact with ordinate, subordinate and client.

According to the analysis of weakness in practical work either in school or industry, it needs to develop work-based learning which is able to achieve the target. It must bridge school and industry through the integrated operational instruction linking theory and application in a practical work from beginning to end; choosing a place, agreement letter ( a school with industry), assessment and evaluation. This integrated model can count the achievement in practical work actually in the industry and can be work reference to school to build curriculum actually in light wheel technic. 


\section{METHOD}

The study was research and development $(\mathrm{RnD})$. The population was all the students in vocational school having practical work in the industry in Yogyakarta 2016. The data is collected by inventory, observation sheet, documentation and deep-interview. The analysis data was validated by some experts/ expert judgement.

\section{DISCUSSION}

\section{Model Development}

After testing the data, the researcher found revised model from hypothetic to empiric Integrated work-based learning (IWBL). The revise analyze: 1) theoretical review; philosophical, methodological perspectives and classroom practice. 2) empiric model; the activity weakness. The limited testing was done to ensure 1) the agreement letter between school and industry. 2) the matrix of IWBL journal. This picture is the description;

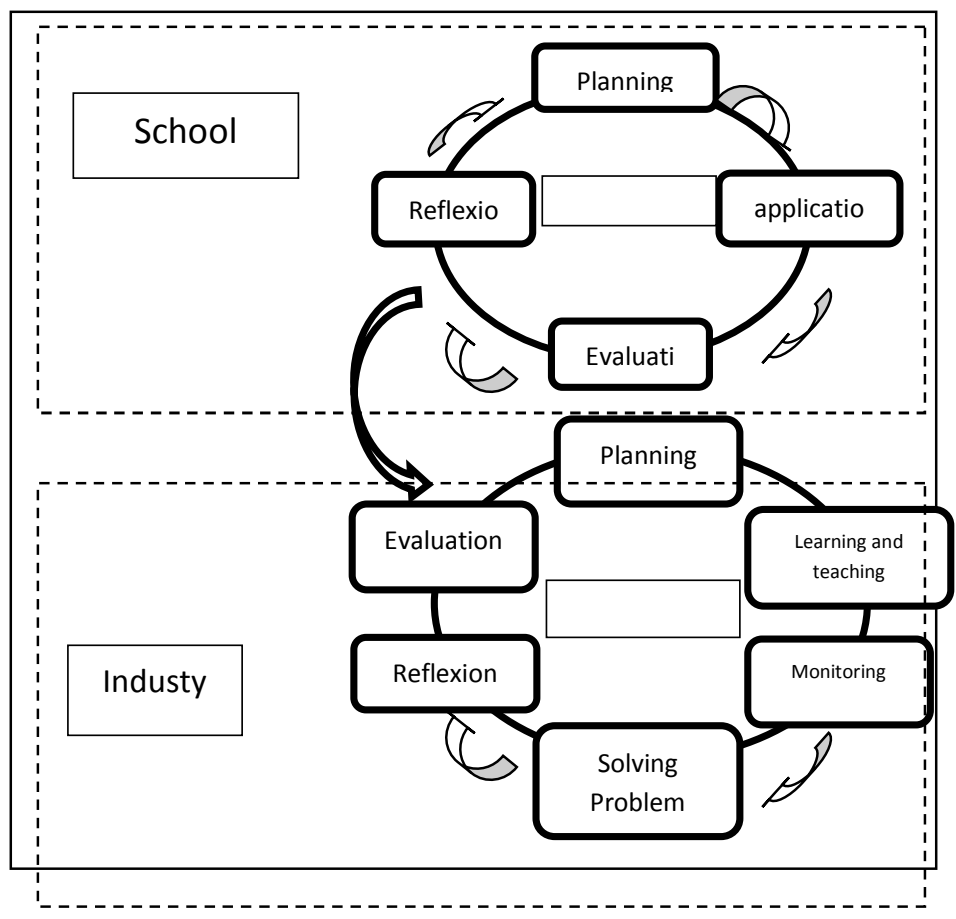

Fig. 1. Empirik WBL-T Model

\section{Validity to guidance book Model IWBL}

Guidance book consists of guidance model, teacher's book/instructor, student's book. All guidance books must have been validated by some experts in industry, lecturer and school. So the result describes on Table 1. After validating from 12 experts, the average shows up to 4 . Nine experts gave 4 (good) with grade B and a bit revision. They said it is appropriate with the industry. Three other experts gave 5 (very good) with grade A. it means no revision. They said it is very good and appropriated with the requirement in industry. So the result is IWBL guidance book of light wheel technic competence is valid for the industry.

TABLE 1. VALIDITY IWB MODEL

\begin{tabular}{|c|l|c|}
\hline NO & \multicolumn{1}{|c|}{ Description } & Total \\
\hline 1 & Basic application was showed clearly & 51 \\
\hline 2 & Model component was showed clearly & 52 \\
\hline 3 & The content was showed clearly & 50 \\
\hline 4 & The step of learning was showed clearly & 53 \\
\hline 5 & The attachment was showed clearly & 52 \\
\hline 6 & Using Bahasa & 51 \\
\hline 7 & Communicative problem statement & 50 \\
\hline 8 & Communicative instruction & 49 \\
\hline 9 & Not using ambiguous word & 47 \\
\hline 10 & General scoring & 53 \\
\hline & Total & 508 \\
\cline { 2 - 3 } & Average & 4.23 \\
\cline { 2 - 3 }
\end{tabular}

\section{Observation of IWBL application}

The researcher has done the observation directly, it shows three indicators referring IWBL: (1) interaction between the students with instructor, (2) adaptation, (3) working with SOP.

The interaction between the students with the instructor. The important point in cooperation is there is interaction. It is between worker and instructor. Here, it shows the increasing interaction during the first four weeks, then stagnancy in the fifth week.becaouse of boredom. But the rate is not less than one. Specifically, the process will appear the habit and consistent mentoring

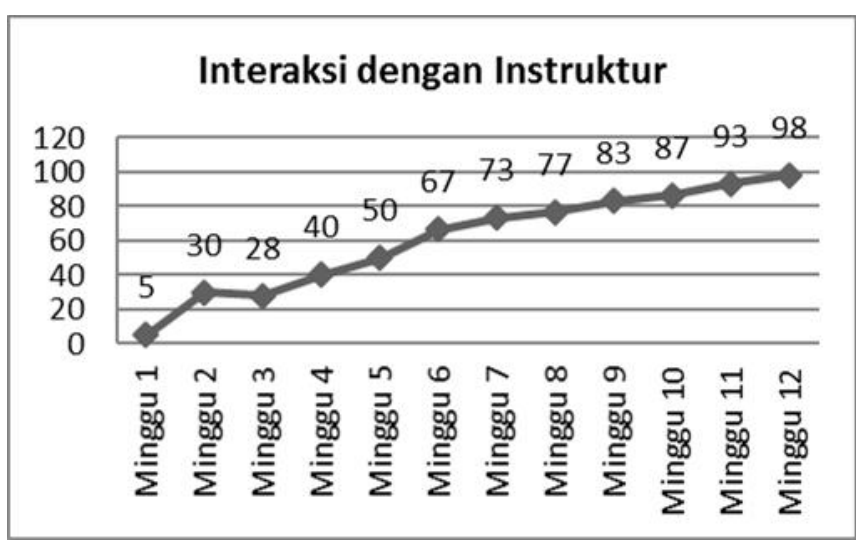

Fig. 2. Interaction between students/workers with instructor

The atmosphere adaptation is also important in cooperation because they have different rule even one cooperation to other cooperation. They have their own rule which must be obeyed by the worker. The adaptation is including tool work, place, worker, friends even a client. The Data shows in the first two weeks, the student was still in school and no rate for student's adaptation but after four weeks the rate increased in $97 \%$. 


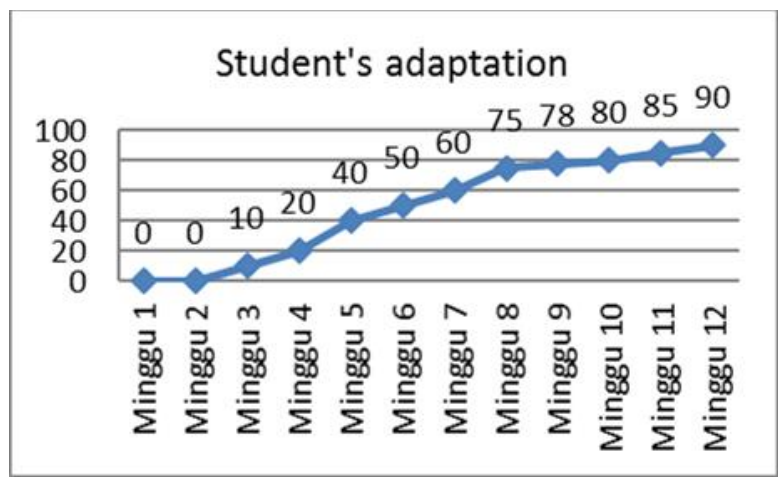

Fig. 3. Student's adaptation

The student must work with SOP Standard Operasional Procedure. In the percentage the rate shows increased in the first to sixteenth week. The first week shows $10 \%$ and the twelveth shows $97 \%$. The process works well.

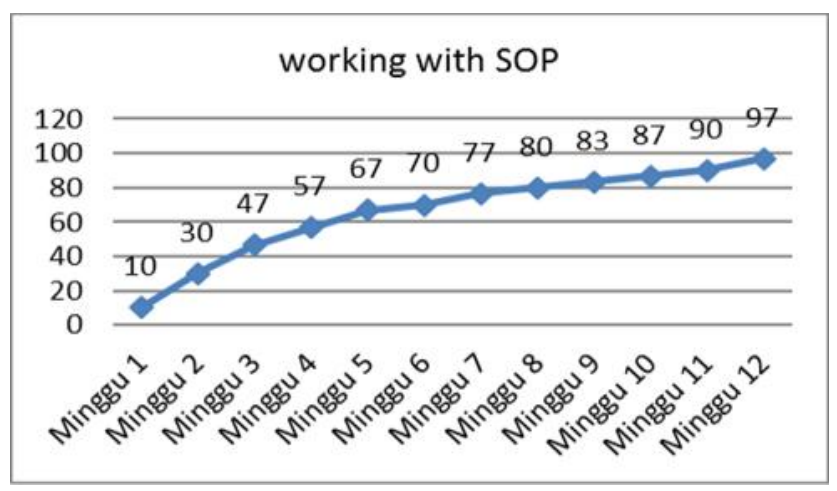

Fig. 4. Working with SOP

\section{Student's Response}

The researchers collect them and conclude the 2 indicators (1) they can be motivated by the IWBL model (2) they agree if it is applied in school. They are 11 points:

TABLE 2. STUDENT'S RESPONSES

\begin{tabular}{|l|l|c|}
\hline \multicolumn{1}{|c|}{ No } & \multicolumn{1}{|c|}{ STATEMENT } & AVERAGE \\
\hline \multicolumn{1}{|c|}{ I. they can be motivated by the IWBL model } \\
\hline 1 & I am satisfied with this model & 4.35 \\
\hline 2 & It is communicative & 4.25 \\
\hline 3 & It makes me learn actively & 4.25 \\
\hline 4 & It makes me curious & 4.5 \\
\hline 5 & I will be active explorer & 4.45 \\
\hline 7 & I am interested in practical work & 4.45 \\
\hline 8 & I want to do more & 4.45 \\
\hline & Sub-average & $\mathbf{4 . 3 9}$ \\
\hline & \multicolumn{1}{|c|}{ II. they agree if it is applied in school } \\
\hline 9 & It is better than model in school & 3.95 \\
\hline 10 & I agree if it is applied in school & 4.3 \\
\hline 11 & It is innovative and well-planned & $\mathbf{4 . 2 2}$ \\
\hline & Sub-average &
\end{tabular}

We will see from this anquette that there are 2 indicators 1) they can be motivated by the IWBL model has average 4,39 meaning they are motivated in using IWBL. 2) they agree if it is applied in school has average 4,22, meaning that it is good to apply this model in vocational school majoring in light wheel technic.

\section{CONCLUSION}

According to the study, it can conclude 1) it is needed development of a conceptual model by philosophical level, theoretical level, methodological level, and classroom practice. 2) after validation by 12 experts to this book, it shows average up to 4 , meaning the book can be applied in school majoring light wheel technic, 3) according to the process using IWBL model, it appears three indicators which will make the work increase: 1) interaction between student and instructor, 2) adaptation, 3) working with SOP. All indicator will create the achievement in success. And 4) from the student's response, it shows a) the student can be motivated by the IWBL model and b) The student agrees to use that model in school. Point a shows average 4.39 meaning they are interested in leaning by using that model and point $\mathrm{b}$ shows average 4.22 shows that they agree if IWBL model can be applied to school as soon as possible.

The recommendations of the study are: 1) the product of IWBL can be alternative for the development of practical work in school. It is for building the student's knowledge etiquette and skill. 2) for the teacher and mentor, it can be the guide book when the student does practical work in school, 3 ) both basic concept and development of the model can be a reference for next study about work-based learning.

\section{REFERENCES}

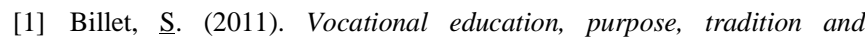
prospect. New York. Springer

[2] Boud D. Solomon N. (2001) Work-Based Learning: Anew higher education. Buckingham, open university Press.

[3] Brite, Jan. (2013). Arizona Work-Based Learning Resource Guide. West Jefferson: Lynne Bodman Hall

[4] Finch, Curtis R. \& Crunkilton, John R. (1999). Curriculum development in vocational and technical education. planning, content, and implementation. Sidney: Allyn and Bacon Inc.

[5] Kuswana, Wowo Sunaryo. (2013). Filsafat Pendidikan Teknologi, Vokasi dan Kejuruan. Bandung: Alfabeta

[6] Murphy, P. \& McCormick, R. (2008). Knowledge an practice, representations and identities. London

[7] Rupert Maclean \& David N. Wilson (2009) International Handbook of Education for the Changing World of Work. Bonn: Springer

[8] Wardiman Djojonegoro. (1998). Pengembangan Sumber daya manuasia melalui sekolah mengah kejruuan (SMK). Jakarta : Jayakarta Agung Offset

[9] Suyitno. 2016. Pengembangan Multimedia Interaktif Pengukuran Teknik untuk Meningkatkan Hasil Belajar Siswa SMK. Jurnal jptk.uny Vol 23, No $\quad 1$ (2016) http://journal.uny.ac.id/index.php/jptk/article/view/9359. Di akses 30 Mei 2016.

[10] Suyitno. 2015. Evaluasi pelaksanaan praktik industri SMK di Yogyakarta. Autotech. vol.06/No.02/Juni 2015. http://ejournal.umpwr.ac.id/index.php/autotext/article/view/2318. Diakses tanggal 10 Mei 2016. 